which will prevent the rest of the doctrine from falling into impossible inconsistency,,$^{\circ}$ tends to emphasize reliance as a determining factor in the enforcement of promises, rather than "bargained-for" and "agreed upon" detriment or benefit. ${ }^{5}$ In this respect, the development is not unlike that of "deceit" notions in the field of torts. ${ }^{2}$ Both have arisen in response to modern notions of fairness, which in many instances are incompatible with the strict rule of consideration. The initial reaction to fact situations such as that presented by the Continental Ill. Bank case is generally one favoring recovery for the subcontractor, primarily because of the reasonable foreseeability of the reliance and resulting damage. The law probably serves its function better when it conforms to such prevailing notions of fairness.

Nevertheless, the re-emergence of the reliance principle of enforcing promises has met with the inertia of the courts, and there is at least some doubt today as to whether even a court which recognizes the general applicability of Section go would care to hold that its protection may extend to third parties, as has been here suggested. However, as neither the policy underlying promissory estoppel nor the cases upholding it preclude such an application of the doctrine, there is considerable likelihood of its development in the direction indicated. Of course, in regard to the specific problem of providing protection for the subcontractor, the preferable alternative would be action by Congress further narrowing governmental immunity, at least in respect to subcontractors' claims for damages.

\title{
MATERIAL WITNESSES AND "INVOLUNTARY" CONFESSIONS
}

Confessions secured through the commitment of persons as material witnesses for "John Doe" proceedings may test the extent to which the Supreme

and Morals 40 (r924); Lorenzen, Causa and Consideration in the Law of Contracts, 28 Yale L. J. $62 x, 643-46$ (r9xg); Ballantine, Is the Doctrine of Consideration Senseless and rllogical?, II Mich. L. Rev. 423 (IgI3).

${ }^{50}$ American Law Institute, Proceedings, Vol. IV Appendix, at II 2.

5x For analogous development in England of enforcement of promises on the basis of detrimental reliance, see Unger, The Twilight of Consideration, I4 Solicitor 76 (I947).

52 There has been gradual relaxation of the requirement that subjective intent to deceive must be an element of a cause of action in deceit. Judicial Recognition of the Promissory Estoppel Section in the Contracts Restatement, 36 Ill. L. Rev. $x 87$, x96 n. 43 (I94r). It has been suggested that promissory estoppel is a principle influencing both torts and contracts and should not be categorized as belonging to either. Ibid., at 203;80 U. of Pa. L. Rev. 594 (1932), noting Saunders v. Galbraith, 40 Ohio App. 155, I 78 N.E. 34 (I93I). Indeed, the doctrine bears a striking resemblance to the action sounding in tort given at early common law for nonperformance of a promise which another had relied upon to his detriment. Willis, Consideration in the Anglo-American Law of Contracts, 8 Ind. L. J. I53, I59 (I932); Ames, The History of Assumpsit, 2 Harv. I. Rev. I, I5 (x888).

A modern view favoring extension of the application of tort principles to such cases of "nonfeasance" is excellently presented in Liability in Tort for the Negligent Nonperformance of a Promise, 45 Harv. L. Rev. I64 (193I), and this view is applied in respect to a well known contracts case, in 82 U. of Pa. L. Rev. 648 (I934), noting Comfort v. McCorkle, I49 N.Y. Misc. 826, 268 N.Y. Supp. I92 (I933). 
Court will go in interfering with state criminal procedure in order to protect individual rights. The recent New York case of People $v$. Perez indicates the possibility that police will use this method of detaining suspects in an effort to secure confessions.

The Supreme Court made its first pronouncement with respect to the use of confessions in cases arising in state courts in Brown v. Mississippi. ${ }^{2}$ Beginning with the Brown case, decided in 1936, the Court has expounded the constitutional doctrine prohibiting the use of confessions obtained under circumstances which violate the requirements of due process of law, that is, "involuntary" confessions. ${ }^{3}$ The Court's decisions indicate that the validity of a confession must be tested by all the circumstances surrounding its taking; ${ }^{4}$ the Court examines these conditions ${ }^{5}$ in order to determine the existence of physical or psychological coercion, either of which is sufficient to vitiate a confession. ${ }^{6}$ In

$\times 300$ N.Y. 208 , go N.E. 2 d 40 (x949), supplemental opinion rendered 300 N.Y. 647,90 N.E. $2 d 499$ (I950), cert. den. 70 S. Ct. $5^{6 I}$ (I950).

$=297$ U.S. 278 (1936).

3 The doctrine arose under the due process clause of the Fourteenth Amendment. Cases cited note 6 infra. Although the Court has stated that the validity of a confession under the constitutional test is independent of the test for an involuntary confession [see Lisenba v. California, 3r4 U.S. 2r9, 236 (I94 I)], the latest opinions indicate that the terms "coerced" and "involuntary" are used as alternative words for "due process." See Watts v. Indiana, 338 U.S. 49 (I949). In using the term " 'involuntariness' doctrine" in this comment it is intended that the due process test be understood.

This comment does not consider the problem of submitting to the jury the question whether the circumstances surrounding the taking of the confession violate the due process clause. Although it might seem an analogous problem to that of admission, analysis indicates that the jury is not likely to disregard a confession unless it appears untrue in an absolute sense. If the validity of a confession is to be questioned on any other ground, the judge must apply the desired test during a preliminary hearing prior to admission of the confession into evidence. Compare 3 Wigmore, Evidence \$ 86x (rev. ed. 1940); McCormick, Some Problems and Developments in the Admissibility of Confessions, 24 Tex. L. Rev. 239, 25 I (I946).

4 The Court has indicated that the issue is determined independently of the truth of the confession. Lisenba v. California, 314 U.S. 2 I9 (I94I).

5 At least two methods have been used by the Court in ascertaining the facts upon which to base its decision of the constitutional issue. The Court has generally accepted the determination of the state court as to what occurred unless "it [was] so lacking in support in the evidence that to give it effect would work that fundamental unfairness which is at war with due process." Lisenba v. California, $3 I_{4}$ U.S. $2 I_{9}, 238$ (I94I). On the other hand, the Court has based at least one of its decisions on the "undisputed testimony." Haley v. Ohio, 332 U.S. 596,598 (r948). In its latest decision the Court stated: "[T]here has been complete agreement that any conflict in testimony as to what actually led to a contested confession is not this Court's concern. Such conflict comes here authoritatively resolved by the State's adjudication. Therefore only those elements of the events and circumstances in which a confession was involved that are unquestioned in the State's version of what happened are relevant to the constitutional issue here." Watts v. Indiana, 338 U.S. 49, 5I-52 (I949).

6 The Supreme Court has decided the following cases involving the question whether a confession was given under circumstances which violated the due process clause (unless otherwise indicated, the conviction was reversed): Watts v. Indiana, 338 U.S. 49 (I949); Turner v. Pennsylvania, $33^{8}$ U.S. 62 (r949); Harris v. South Carolina, 338 U.S. 68 (1949); Haley v. Ohio, $33^{2}$ U.S. 596 (r948); Malinski v. New York, 324 U.S. 401 (I945); Lyons v. Oklahoma, 322 
handling these cases the Court has expressed its reluctance to interfere with the administration of state criminal law ; $^{7}$ it has acknowledged, however, that the due process clause places a duty upon it to review state convictions ${ }^{8}$ and potentially gives it broad powers for this purpose. 9

The Perez case invites analysis of a procedure not yet tested under the "involuntariness" doctrine. A murder and burglary were committed on Tuesday, March 30, I948. The defendant was arrested shortly after noon, Friday, April 2, after attempting to pawn some of the stolen articles. Subjected to almost continuous questioning for the next twenty-four hours, the defendant revealed that he had, on March 30 , pawned other articles sought by the police as among those stolen. Police recovered these items and acquired the remainder of the loot from the defendant's uncle. During his interrogation, the defendant indicated that various people had given him the stolen property, but each "lead" proved worthless. At noon, Saturday, April 3, the defendant was taken before a judge, who committed him as a material witness for a "John Doe" proceeding, in default of $\$ 50,000$ bail. ${ }^{10} \mathrm{He}$ was then taken to the city prison and remained

U.S. 596 (I944) (conviction affirmed); Ashcraft v. Tennessee, 322 U.S. I43 (I944), 327 U.S. 274 (I946); Ward v. Texas, 3 I6 U.S. 547 (I942); Lisenba v. California, 3I4 U.S. 2I9 (I94I) (conviction affirmed); Lomax v. Texas, $3^{\text {I3 }}$ U.S. 544 (r94I); Vernon v. Alabama, $3^{1} 3$ U.S. 547 (I94I); White v. Texas, 3 Io U.S. 530 (I940); Chambers v. Florida, $3 \circ 9$ U.S. 227 (I940); Cantby v. Alabama, $3 \circ 9$ U.S. 629 (I940); Brown v. Mississippi, 297 U.S. 278 (1936).

Various factors have been considered in the cases as follows:

Actual physical abuse: Lomax, White, and Brown cases. Threatened physical abuse: Malinski and Chambers cases. Extended questioning: Watts, Turner, Harris, Haley, Ashcraft, Ward, Lisenba, Lomax, Chambers and Cantby cases. Denial of counsel or failure to inform the suspect of his rights: Watts, Turner, Harris, Haley, Malinski, and Chambers cases. Incommunicado holding of the defendant: Watts, Turner, Harris, Haley, Malinski, Ashcraft, White, Chambers and Cantby cases. Deprivation of food and drink: Watts case. Denial of sleep: Watts and White cases. Illegal detention: Watts, Turner, Harris, Malinski, Ward, White and Chambers cases. Inhuman surroundings: Watts and Turner cases. The age, race, education and other characteristics of the confessor: Turner, Haley, Ashcraft, Lisenba, Ward, Chambers, Cantby, and Brown cases.

7 Watts v. Indiana, 338 U.S. 49, 50 n. I (r949); Malinski v. New York, 324 U.S. 401,418 (I945); McNabb v. United States, 318 U.S. 332, 340 (I943).

${ }^{8}$ Watts v. Indiana, 338 U.S. 49,50 ( 1949 ).

9 Ibid., at $50 \mathrm{n}$. I.

so Neither the opinion nor the dissent of the Court of Appeals of New York indicates the type of proceeding for which the defendant was committed as a material witness. Since the statute [New York Crim. Code (McKinney, I945) §6r8(b)] requires that the person committed be "a necessary and material witness for the people in a criminal action or proceeding pending in any of the courts of this state," and since pending grand jury investigations are generally required as a minimum to comply with the statute [see People ex rel. Nuccio v. Warden of Eighth District Prison, $x 82$ N.Y. Misc. 654,45 N.Y.S. $2 \mathrm{~d} 230$ (r943)], it would seem a fair inference that some grand jury proceeding was pending at the time of the defendant's commitment as a material witness. That proceeding might have been entitled "People v. John Doe" since such proceedings are often used in New York. Ibid. Or, the proceeding might have been labelled "People v. Danny Miles" since the defendant had stated prior to his commitment that he had received the property he had pawned from a person named Danny Miles. Respondent's brief on reargument at 5 (semble). Since the police questioned the defendant subsequent to 
there undisturbed until Monday, April 5. Beginning on Monday afternoon, the defendant was questioned for long periods each day." Daily interrogations continued, with the exception of Wednesday, until the defendant confessed, Friday, April 9, to the murder and burglary. At his trial the court admitted into evidence the confession and testimony regarding the circumstances surrounding its taking. The defendant testified that he had been beaten and deprived of clothing, food, drink and cigarettes prior to his confession. Witnesses for the prosecution denied this testimony. The defendant also testified that during his commitment he had been refused permission to contact counsel by a police captain who told him he was being held incommunicado. Although the police captain testified, this allegation was not denied. It appeared that the defendant had made no other request for counsel although he later talked with the assistant district attorney who had advised him of his right to counsel at the time he was committed. The jury found the defendant guilty, and he was sentenced to death. The Court of Appeals of New York affirmed the conviction, two judges dissenting. ${ }^{12}$ The Supreme Court denied certiorari. ${ }^{13}$

It is doubtful whether the confession in the Perez case satisfies the standards established by the Supreme Court's decisions. ${ }^{14}$ With respect to his interrogation alone, the defendant was, according to the prosecution, "subject to

his commitment and continued to do so after the defendant had accused other persons of the crime, the police, in effect, were holding him as a witness against an "unknown" criminal. Further insight into the methods of the police is gained through the fact that the defendant's wife and cousin were also held as material witnesses. Respondent's brief for reargument at $7_{k}$

x Text at note $I_{5}$ infra.

12 People v. Perez, 300 N.Y. 208, go N.E. 2d 40 (1949). The questions on appeal involved the admission of the confession into evidence and the failure of the trial court to give certain charges to the jury as requested by the defendant. The court of appeals held that physical a buse was not established so as to preclude admission, distinguishing the latest decisions of the Supreme Court on the ground that the defendants were illegally detained in those cases. The trial court had charged that the jury might consider the confession only if found voluntary; it had refused to charge that the jury might not convict the defendant if the confession were found involuntary. The court of appeals held that the refusal to charge was proper because evidence other than the confession would have justified conviction. But see Watts v. Indiana, 338 U.S. 49,50 n. 2 (1949). The trial court also refused "to charge that the jury might consider" defendant's detention prior to commitment, any "unnecessary delay in arraignment, and all circumstances surrounding the taking of the confession, in determining whether [the confession] was voluntary." People v. Perez, go N.E. 2d 40, 45 (r949). The court found the refusals proper because, even though the defendant's detention prior to his commitment was not covered in the charge, the other issues were covered in the charge and the illegal detention was not "an efficient cause of the confession." Ibid., at 46 . Concerning the commitment as a material witness, the court stated that the jury could not have found that it was a "sham" procedure for holding the defendant because there was ample reason for such commitment at the time. The dissent stressed the failure of the trial court to charge the jury that the defendant had a right to prompt arraignment and that illegal detention must be considered in determining the voluntariness of the confession.

${ }^{2}$ People v. Perez, 70 S. Ct. 56r (1950).

14 The denial of certiorari is inconclusive. See Frankfurter, J., in State v. Baltimore Radio Show, 70 S. Ct. 252, 254 (1950). 
questioning for a total of thirty-two out of seventy-six hours"'s5 during his commitment. In the Ashcraft ${ }^{16}$ case the defendant was questioned for thirty-six consecutive hours and the Court found the circumstances surrounding the taking of his confession "inherently coercive." "More recent decisions have emphasized the coercive aspects of protracted questioning, even though it is not continuous. ${ }^{18}$ The protracted questioning of the defendant in the principal case, coupled with the denial of counsel by at least one police officer ${ }^{\text {I9 }}$ and the original period of illegal detention, ${ }^{20}$ raises serious questions regarding the constitutionality of the admission of the confession.

The Perez case suggests a procedure which police might adopt to detain suspects. ${ }^{2 I} \mathrm{~A}$ crime is committed. The police pick up one or a number of suspects.

xs Respondent's brief at 20.

${ }^{26}$ Ashcraft v. Tennessee, 322 U.S. I43 (I944).

I7 Ibid., at 154 .

${ }_{28}$ Watts v. Indiana, 338 U.S 49 (I949); Turner v. Pennsylvania, 338 U.S. 62 (I949); Harris v. South Carolina, 338 U.S. 68 (I949); Haley v. Ohio, 332 U.S. 596 (I948). The Court stressed two factors in its decision in the Ashcraft case- unremitting questioning, and the holding of the defendant incommunicado. In the Watts case the Court stressed the extended and repeated periods of questioning while the defendant was illegally detained, held incommunicado and accorded few decent privileges with respect to quartering, food and drink.

19 The Court of Appeals of New York indicates that a person committed as a material witness is entitled to counsel. People v. Perez, go N.E. 2d 4O, 45 (I949); see The Substance of the Right to Counsel, I7 Univ. Chi. L. Rev. 7I8 (I950). Denial of counsel has been considered a factor in many Supreme Court decisions. Cases cited note 6 supra.

${ }^{30}$ The Court of Appeals of New York adopted the position that even if the defendant's detention prior to his commitment as a material witness was unlawful (a point which the court did not decide), it was irrelevant to the issue because it was not "an efficient cause of the confession." Ibid., at 46 . The court's position might have been defended under the authority of Lyons v. Oklahoma, 322 U.S. 596 ( $(944$ ), if all coercive practices had terminated at the time of the defendant's commitment as a material witness. However, the subsequent questioning of the defendant indicates that the pressures did not cease with commitment. Thus, the period of illegal detention ought to have been considered, under the "involuntariness" doctrine, as a part of the totality of circumstances determining the validity of the confession. Cases cited note 6 supra. Moreover, even if the illegal detention were not a causative factor, it indicates a complete disregard of the defendant's rights and is relevant to the issue on that point. Compare Haley v. Ohio, 332 U.S. 596 (1948).

${ }^{2 x}$ This comment is not concerned with analyzing the detention of persons who are, in fact, material witnesses. It seems that no recent study has been made of the practice. Some guarantee that witnesses will give their testimony is certainly necessary. Lengthy detention, on the other hand, is most undesirable. Most states regulate the treatment of witnesses for criminal proceedings by statute. Generally, witnesses are required to post a bail bond where it appears likely that they will abscond. See The Administration of Bail, 4I Yale L.J. 293, 298 n. 4 I (I93I); Medalie, A Symposium on the Subject of Material Witnesses, 8 The Panel, No. I, at I (Jan.-Feb., I930); Judd, Material Witnesses, 8 The Panel, No. 3 at 7 (May-June, r930); American Law Institute, Code Crim. Proc., Commentary to $\$ \S 56-58$ (I93I). Failure to post the bail bond subjects the witness to commitment. Authorities cited supra. Suggestions respecting the seasonable examination of the witness in the presence of the accused, the speeding-up of the accused's trial and interstate exchange of witnesses have been made in order to obviate the harsh result of lengthy detention. Medalie, op. cit. supra. With respect to the detention of material witnesses for "John Doe" proceedings, valid reasons may also be given for the deten- 
Questioning produces no results. In order to comply with the requirements of the material witness statute, an official appears before a grand jury and testifies to the details leading to the belief in the existence of a crime.2z Thereafter, the suspect, having been illegally detained during this time, ${ }^{23}$ is taken before a magistrate who sets bail ${ }^{24}$ and, in default, commits him as a material witness for a "John Doe" proceeding. ${ }^{25}$ The witness' commitment can continue as long as the proceeding remains pending. ${ }^{26}$

This procedure may be selected as an alternative to three other types of action open to police. Release of the person under suspicion is obviously unlikely. ${ }^{27}$

tion of the witness. The desire to guarantee the presence of the witness when the defendant is apprehended speaks for this procedure where there is likelihood that the witness will abscond or be spirited away by the guilty person. The procedure ceases to be defensible when it is used as a means of detaining one suspected of the crime for purposes of obtaining evidence to be used against him. Whenever a confession is obtained from such a "witness" it may be difficult to distinguish the spurious from the genuine material witness. Text at note 40 infra.

22 It is immaterial when the official appears before the grand jury so long as there is a grand jury proceeding against "John Doe" pending at the time of the witness' commitment. Compare People ex rel. Nuccio v. Warden of Eighth District Prison, I82 N.Y. Misc. 654, 45 N.Y.S. $2 \mathrm{~d} 230$ (r943).

23 In practice, police might apprehend a suspect after a grand jury proceeding is pending against "John Doe." In that event illegal detention becomes unnecessary.

24 Of course, the requirement of a bail bond does not prevent incarceration as a practical matter. Bail may be set at a prohibitive figure. $\$ 50,000$ proved effective in the Perez case; $\$ 250,000$ has been held not excessive in detention of material witnesses for a murder investigation. People ex rel. Rao v. Adams, 296 N.Y. 23I, 72 N.E. 2d I70 (x947).

${ }_{25}$ This comment is not concerned with ascertaining how many states might allow commitment of material witnesses for "John Doe" proceedings. However, it is clear that most states will allow the commitment of material witnesses. Authorities cited note 2I supra. Generally, statutes provide that the witness is entitled to a hearing. Medalie, op. cit. supra note $2 \mathrm{I}$; Judd, op. cit. supra note 2I; American Law Institute, op. cit. supra note 2r. The witness is usually committed only in default of bail. Authorities cited supra.

${ }^{26}$ It is doubtful whether a witness can appeal his order of commitment in New York. People v. Doe, 26r App. Div. 504, 26 N.Y.S. 2d $45^{8}$ (rg4r) (appeal denied); In re Prestigiacomo, 234 App. Div. 300,255 N.Y.S. 289 (1932) (appeal allowed); In the matter of DiPiazzi, 234 App. Div. 302,255 N.X.Supp. $29 \mathrm{I}$ (I932) (appeal allowed). A petition for a writ of habeas corpuswill be denied unless the witness can prove that a proceeding is no longer pending or that there was a deviation from proper commitment procedures. See People ex rel. Nuccio v. Warden of Eighth District Prison, 182 N.Y. Misc. 654, 45 N.Y.S. 2d 230 ( 1943 ). Dicta in the Perez case indicate that the witness might secure release if he could prove that police had sufficient information upon which to arraign him at the time of his commitment. People v. Perez, 90 N.E. 2d 40,46 (1949); cf. Matter of Bernoff v. Amoroso, I88 N.Y. Misc. 845, 65 N.Y.S. 2d 810 (I946). Investigation as to the length of time normally consumed in effectuating the release of material witnesses for "John Doe" proceedings would prove quite helpful. In any event, material witnesses committed for such purposes have been denied release in New York at least fifty-five days after their commitment. People ex rel. Nuccio v. Warden of Eighth District Prison, I82 N.Y. Misc. 654,45 N.Y.S. $2 d 230$ (1943).

${ }^{27}$ In practice, police have often carried on "sweeping" investigations. People who might have some connection with, or knowledge of, many crimes are arrested and subjected to questioning and other practices in attempts to get information. Nat'l Comm'n on Law Observance and Enforcement, Report on Lawlessness in Law Enforcement 162 (I93I). 
Continuation of the illegal detention is also undesirable from the police viewpoint because it is one of the circumstances determinative of the voluntariness of a confession. ${ }^{28}$ Finally, the police might take the suspect before a magistrate for a preliminary hearing with a view to having him committed as a defendant. In the Perez case the defendant, upon his apprehension, might have been taken before a magistrate with respect to commitment for murder and burglary or for the possession of stolen goods. ${ }^{29}$

From the viewpoint of police and prosecuting officials, it is desirable to delay commitment as a defendant until enough evidence has been acquired to insure a fair chance of conviction. If they do not have sufficient evidence at the time of commitment, they assume the risk of either obtaining such evidence subsequently or of being embarrassed by dismissal or acquittal. In practice there may be many suspects for any one crime, and delaying commitment enables police to seek sufficient evidence both through the suspects and through independent investigation. Subsequent to commitment, the police may experience difficulties in interrogating a defendant. Consequently, police have adopted various methods of avoiding commitment.

Hitherto, illegal detention has served as one method of avoiding commitment. ${ }^{30}$ During this period various means, ranging from questioning to physical abuse, have been employed to get the suspect to "talk." Police and prosecuting officials might employ such means with the incarcerated defendant. However, committing the suspect as a defendant sharply curtails the opportunity to carry on these activities. The defendant can then obtain counsel to protect his interests; moreover, the police may experience difficulty in attempting to remove him from jail or to question him without his consent. Since police will generally be seeking evidence through the suspect who is illegally detained, and protection of counsel will generally be absent during this period, the likelihood of "coercive" practices being employed is manifest. Nevertheless, in reviewing state cases, the Supreme Court has been unwilling to apply the $M c N a b b^{3 \mathrm{r}}$ rule which denies admission to any confession obtained by federal officers during a period of illegal detention..$^{32}$ The Court has preferred to rest its decisions on the

${ }^{28}$ Cases cited note 6 supra.

29 If the defendant in the Perez case were committed as a defendant for the possession of stolen goods and subjected to questioning regarding the murder and burglary, one would expect the Supreme Court to treat such questioning and any other practice employed as factors in determining the voluntariness of any confession obtained. One might also expect the Court to criticize police for using such a means of detaining a suspect in order to acquire a confession. However, in the only state case in which the defendant was committed on a lesser charge and questioned with respect to a murder, the Court mentioned the fact only in passing. Lisenba $v$. California, 3I4 U.S. $2 I_{9}$ (I94I).

${ }^{30}$ Nat'l Comm'n on Law Observance and Enforcement, op. cit. supra note 27; cases cited note 6 supra.

${ }^{31}$ McNabb v. United States, 3I8 U.S. 332 (x943).

32 Justice Douglas accepted this view in concurring opinions in the latest state cases before the Court; the majority, however, based its opinion on the totality of circumstances sur- 
totality of circumstances surrounding the taking of the confession, considering illegal detention as a factor, but not as determinative. ${ }^{33}$

The position taken by the Court leads to serious problems because of the probability that "coercive" methods will be employed during illegal detention and the difficulty of establishing their use in any particular case. The suspect will often be alone with police and prosecuting officials during this time. If there is a dispute as to what actually occurred, its resolution by the state court precludes the Supreme Court from reviewing the evidence unless giving effect to the state court's determination "would work that fundamental unfairness which is at war with due process." ${ }^{34}$ But, even if the Court could decide the "involuntariness" issue on the basis of what actually occurred, the task of evaluating the "coerciveness" of those circumstances would still remain. Instead of resolving this issue by some arbitrary standard of "coercion," the exposure of individuals to practices so fraught with "coercion" and so much in conflict with our "accusatorial system" 35 of criminal procedure ought to be condemned. Thus, the view expressed by Justice Douglas seems preferable: "We should ... stand ready to outlaw ... any confession obtained during the period of the unlawful detention." 36

The arguments concerning illegal detention are applicable to any type of procedure designed to avoid commitment of a suspect as a defendant. Commitment of suspects as material witnesses for "John Doe" proceedings is one procedure which police and prosecuting officials might adopt, at least in New York, ${ }^{37}$ in an attempt to detain suspects legally and to obviate the stigma attached to illegal detention. The Court of Appeals of New York indicated in the Perez case that it would not allow its statute requiring prompt arraignment ${ }^{38}$ to be circumvented where "prosecuting authorities had enough information to

rounding the taking of the confession. Watts v. Indiana, 338 U.S. 49 (r949); Turner v. Pennsylvania, 338 U.S. 62 (1949); Harris v. South Carolina, 338 U.S. 68 (1949). The McNabb rule, based on statutory and not constitutional interpretation, has been the object of adverse criticism from various sources. Inbau, The Confession Dilemma in the United States Supreme Court, 43 Ill. L. Rev. 442, 452-53, 459-63 (x948); Waite, Police Regulation by Rules of Evidence, 42 Mich. L. Rev. 679, 688-92 (I944); but see McCormick, op. cit. supra note 3, at 275 . When the question of the incorporation of this rule into the Federal Rules of Criminal Procedure came before the American Bar Association, it was rejected. See Holtzoff, Institute on Federal Criminal Rules, 29 A.B.A.J. 603 (r943). Congress has considered an amendment to the Rules of Criminal Procedure which would eliminate the rule, but it has never been enacted. See 89 Cong. Rec. 97 II (r943); 93 Cong. Rec. I376-92 (I947).

${ }_{33}$ Cases cited note 6 supra. There is a vast amount of literature on the subject of confessions and also on the Supreme Court's treatment of them. See, generally, McCormick, op. cit. supra note 3 , and authorities cited therein.

${ }^{4}$ Lisenba v. California, 3 I4 U.S. 2I9, 238 (I94I); see note 5 supra.

${ }_{35}$ Watts v. Indiana, 338 U.S. 49,55 (r949). ${ }^{36}$ Ibid., at 57 .

37 Commitment of material witnesses for "John Doe" proceedings is evidently a well established practice in New York. See People ex rel. Nuccio v. Warden of Eighth District Prison, 182 N.Y. Misc. 654, 45 N.Y.S. 2d $23^{\circ}$ (1943).

${ }^{38} \mathrm{New}$ York Crim. Code (McKinney, 1945) §618(b). 
arraign [the defendant] ... but procured his commitment as a material witness so as to continue an interrogation which would have been hampered by arraignment."'39

The "involuntariness" doctrine would seem to require a similar view. The considerations which lead one to believe that the police might adopt whatever methods are necessary to make the illegally detained suspect confess or divulge information, lead to the same conclusion with respect to the spurious material witness. The intervention of a magistrate might not assist the spurious material witness because of the existence of the same possibilities of secret interrogation, without the assistance of counsel, as when detention is illegal. The same problems with respect to conflicting evidence, the probability that pressures will be applied, and the task of evaluating alleged "coercion," occur in both procedures. $4^{\circ}$ Thus, as with illegal detention, the desirable rule would be one which excludes all confessions acquired from suspects committed as material witnesses for "John Doe" proceedings even though "coercion" might not be established in a particular case.

The difficult question with respect to material witnesses for "John Doe" proceedings arises when attempts are made to distinguish the spurious from the genuine witness. Distinctions have been drawn in the comparable dilemma of separating the "party" from the witness in grand jury proceedings involving the privilege against self-incrimination. ${ }^{4}$ However, the task of convincing the Court of Appeals of New York that authorities have perverted the material witness commitment procedure in a particular case may be insurmountable since the court does not forbid extended questioning of a material witness. ${ }^{2}$ Police and prosecuting officials might always, under the view of the New York court, maintain that their questioning was directed at a recalcitrant witness who "knew, or might help to ascertain, the [unknown criminal]." 43

39 People v. Perez, go N.E. 2d 40, 46 (x949).

$4^{\circ}$ Considering the aspect of "coercion" simply in terms of the type of detention of the person, it might be argued that commitment as a material witness for a "John Doe" proceeding will be more likely to produce a confession than holding a person as a defendant. Both the defendant and the material witness may be detained in jail for an indeterminate period of time. The defendant has simply to await his grand jury hearing and trial; any time spent in jail during this period will be credited toward his sentence upon conviction. The material witness, on the other hand, has to await the holding of the grand jury hearing; if he later becomes the defendant and is convicted of the crime, the period of his commitment probably will not be credited toward his sentence. Matter of Bernoff v. Amoroso, I88 N.Y. Misc. 845, 65 N.Y.S. 2d 8Io (I946). Because of this lack of credit, material witnesses might be led to confess where they believe the action is, in fact, to be directed against them at some indeterminate future time. This pressure to confess seems manifest where a minor offense is involved; however, it becomes extremely difficult to measure such pressure in more serious crimes.

$4^{2}$ Cases cited in 8 Wigmore, Evidence $\$ 225^{2}$, at 325 n. I2 (rev. ed. r940).

42 This seems odd considering that the primary purpose of a "material witness-commitment ... [is] to guarantee the presence of a witness at the trial. . ." Desmond, J., dissenting in People v. Perez, 90 N.E. 2d 40, 47 (I949).

43 Ibid., at 45. 
The very fact that a confession is obtained from a material witness for "John Doe" indicates a possibility that the confessor was, in fact, suspected of the crime at the time of his commitment. Since there is no easy method of distinguishing between the spurious and the genuine material witness, this possibility alone ought to lead to the condemnation of all confessions obtained from such "witnesses."

In any discussion of the "involuntariness" doctrine these questions arise: What circumstances are "coercive"? What are the consequences of "coercive" circumstances? The words "voluntary" and "involuntary" are of little assistance in answering either of these questions; 44 the same is true of the phrase "without due process of law."

In determining the consequences of "coercive" circumstances, it is necessary to ascertain the purpose of the doctrine. It might be designed only to eliminate confessions which are untrustworthy. ${ }^{46}$ In this event, evidence corroborating the truthfulness of the confession, whether a "fruit" of the confession or acquired independently, would invalidate the ground for denying admission to the confession. On the other hand, the purpose of the doctrine might be to protect individuals from "coercive" practices, irrespective of the truth or falsity of a confession obtained in a particular case. If this is the purpose, not only would confessions resulting from such practices be excluded, but any evidence gained as a "fruit" of the confession would be denied admission. Conviction under such a rule would necessarily depend upon evidence secured independently of the proscribed practice.

The Supreme Court has not passed on the cases which would determine the purpose selected-either where corroborating evidence substantiates the confession or where other evidence is acquired as a "fruit" of the confession. The Court has indicated, however, that corroborating evidence will not render a "coerced" confession admissible. 47 It thus appears that the Court is interested in protecting individuals from "coercive" practices even though such practices might, in a given case, produce a trustworthy confession. However, in order to effectuate such a purpose, the Court must also be willing to deny admission to the "fruits" of the confession..$^{8}$ Otherwise police and prosecuting authorities

${ }^{44} 3$ Wigmore, Evidence $\S 843$ (rev. ed. 1940 ).

${ }_{45}$ Frankfurter, J., concurring in Haley v. Ohio, 332 U.S. 596, 605 (1948).

${ }^{46} 3$ Wigmore, Evidence $\$ \$ 822,826$ (rev. ed. I940).

47 The Court has stated that no "coerced confession is [admissible] under the Due Process Clause even though statements in it may be independently established as true." Watts v. Indiana, 338 U.S. 49 , 50 n. 2 (I949).

${ }^{8}$ The views expressed by the Court in the case of Wolf v. Colorado, 338 U.S. 25 (I949), do not preclude the constitutional prohibition of the use of evidence gained as a "fruit" of an involuntary confession. The Court held in the Wolf case that due process protects individuals against unreasonable searches and seizures but that such protection does not include the prohibition of admission of evidence so obtained. Admission of involuntary confessions, on the other hand, is directly prohibited by the due process clause. If there were no corroborating evi- 
will not be inhibited from carrying on "coercive" practices. They will be able to make use of the "fruits" even though the confession itself is excluded.

Even if the Court should clearly indicate the purpose to be served by the "involuntariness" doctrine and the ramifications of such a purpose in terms of the consequences of "coercive" practices, the problem of determining what are "coercive" practices would still remain. Because the Court has based its decisions on the totality of circumstances surrounding the taking of the particular confession, 49 the states are left to determine the meaning of each decision. Critics of the Ashcraftis decision have been fearful lest police be forbidden to question suspects. ${ }^{51}$ Although the Court has never denied the admissibility of a confession merely because of police questioning, ${ }^{52}$ it has reversed convictions where "coercive" interrogation appeared as a factor. ${ }^{53}$ But, as Justice Jackson observed in his dissent in the Ashcraft case, questioning a person in police custody is "coercive" per se. 54 Under the present system, the police must draw the line between "coercive" and "noncoercive" practices and trust that their distinction agrees with that of the Court. .5

dence for the confession, a distinction between the admission of such a confession and of evidence obtained through an unreasonable search and seizure might be drawn on the ground that the former involves questions affecting the credibility of the evidence while the latter does not. McCormick, op. cit. supra note 3 , at 273 . However, where the confession is corroborated to the extent that its probable truth is established, and the "involuntariness" doctrine excludes it, no such distinction can be argued. See Watts v. Indiana, 338 U.S. 49, 50 n. 2 (r949). Thus, the Court in refusing to hold such a confession admissible indicates that credibility-trustworthiness-is not the objective of the "involuntariness" doctrine; it would seem, in fact, that the Court is concerned with eliminating brutal and inhuman practices, irrespective of the truth of the evidence which might be acquired through them. Thus, under such reasoning, all evidence acquired through such practices would suffer the same condemnation as the confession.

If the Court is willing to exclude a confession which is substantiated by external evidence while admitting any evidence obtained as a "fruit" of the confession, the illogical result achieved might well be criticized. If the Court is really interested only in preventing untrustworthy confessions, it would seem preferable to allow the introduction of the confession where it is corroborated by external evidence and to allow the admission of the "fruits" of an involuntary confession. Compare 3 Wigmore, Evidence $\$ \$ 856-59$ (rev. ed. r940); People v. Valecek, 404 Ill. 46 ז, 463,89 N.E. 2 d 368,370 (I949).

49 Cases cited note 6 supra.

${ }^{50}$ Ashcraft v. Tennessee, 322 U.S. I43 (I944).

sx Justice Jackson, dissenting in Ashcraft v. Tennessee, 322 U.S. 143,156 (1944); Inbau, op. cit. supra note 32 .

${ }_{52}$ "The mere questioning of a suspect while in the custody of police officers is not prohibited either as a matter of common law or due process." Lyons v. Oklahoma, 322 U.S. 596, $60 I$ (I944).

s3 Cases cited note 6 supra.

54 Ashcraft v. Tennessee, 322 U.S. I43, I6I (1944).

55 "If the constitutional admissibility of a confession is no longer to be measured by the mental state of the individual confessor but by a general doctrine dependent on the clock, it should be capable of statement in definite terms. If thirty-six hours is more than is permissible, what about 24? or I2? or 6 ? or I? All are 'inherently coercive.' Of course questions of law like this often turn on matters of degree. But are not the States entitled to know, if this Court is 
Under these circumstances the Court might well consider the advisability of adopting definite rules respecting the admission of confessions under the "involuntariness" doctrine..$^{6}$ In considering the formulation of such rules, the Court must, of course, be cognizant of both the interests of the community in apprehending the criminal and the interests of society in protecting all individuals, guilty or innocent, from exposure to brutal or inhuman treatment. Since pressures are too easily applied to a suspect who is illegally detained ${ }^{57}$ or committed as a material witness for "John Doe" proceedings, , $^{8}$ the Court might adopt rules designed to eliminate the benefits realized from such practices. All confessions obtained through such procedures could be held inadmissible.

Because illegal detention and all other means of avoiding commitment as a defendant would become undesirable under such rules, police and prosecuting officials might attempt to interrogate a defendant after commitment. Or, suspects might be committed on minor charges and questioned with respect to more serious crimes.59 In order to preclude the use of such procedures, the Court could exclude all confessions obtained through questioning an incarcerated defendant. The Court could also indicate that the right to question prior to such incarceration, for purposes of determining the validity of any confession, would be governed by rules, perhaps modeled after the Judges' Rules of England. ${ }^{60}$

There is little doubt that such rules would interfere with the administration of criminal law in the states; they would also interfere with the apprehension and conviction of some criminals..$^{61}$ However, if these rules were linked with a purpose of protecting individuals from abusive practices irrespective of the

able to state, what the considerations are which make any particular degree decisive? How else may state courts apply our tests?" Jackson, J., dissenting in Ashcraft v. Tennessee, 322 U.S. 143 , I62 (I944).

${ }^{56}$ The Court has stated that the objective of due process is to insure that procedures " consistent with the fundamental principles of liberty and justice which lie at the base of all our civil and political institutions" Brown v. Mississippi, 297 U.S. 278, 286 (1936), quoting From Hebert v. Louisiana, 272 U.S. 312, 316 (1926). Within this framework the Court has indicated that the procedures employed in criminal administration must be "accusatorial as opposed to ... inquisitorial." Watts v. Indiana, 338 U.S. 49,54 (I949).

57 Text at notes $30-36$ supra.

${ }^{8}$ Text at notes $36-40$ supra.

59 Note 29 supra.

${ }^{60}$ See St. Johnston, The Legal Limitation of the Interrogation of Suspects and Prisoners in England and Wales, 39 J. Crim. L. 89, 94 (I948). The preliminary hearing might then be made an important part of state criminal procedure. Compare the suggestions of the New York Commission on the Administration of Justice, Second Supplemental Report I4 (I936), reprinted in 3 Wigmore, Evidence $\$ 852$, at 325 (rev. ed. 1940); Kauper, Judicial Examination of the Accused-A Remedy for the Third Degree, 30 Mich. L. Rev. I224 (1932); McCormick, op. cit. supra note 3 , at 277 .

6x Inbau, op. cit. supra note 32 . 
truth or falsity of any confession obtained, they would serve as a possible means of curbing those practices. This would assist in affording each individual suspected of a crime the rights which ought not be infringed but which have been subjected to multifarious encroachments in the past. Moreover, the rules would provide some objective certainty with respect to the admission of confessions and their "fruits," and to that extent, at least, would eliminate the necessity for omniscient insight in determining the presence or absence of "coercion" in particular cases.

\section{THE SUBSTANCE OF THE RIGHT TO COUNSEL}

In federal prosecutions the courts are obligated by the Sixth Amendment to furnish counsel for all indigent defendants. ${ }^{x}$ No such inflexible guarantee is afforded the defendant in a state prosecution. Since the Supreme Court's decision in Betts v. Brady, ${ }^{2}$ an absolute right to counsel prevails only in capital cases. ${ }^{3}$ Trial without counsel for a noncapital offense will not offend due process unless, viewing the "totality of facts," the proceedings are found lacking in fundamental fairness. 4 Relevant to the question of fairness are the age, intel-

I U.S. Const. Amend. 6. "In all criminal prosecutions the accused shall enjoy the right ... to have the assistance of counsel for his defense." In Johnson v. Zerbst, 304 U.S. 458 , 463 ( 1938 ), it was held that "[ $[$ ] he Sixth Amendment withholds from federal courts, in all criminal proceedings, the power and authority to deprive an accused of his life or liberty unless he has or waives the assistance of counsel." See Foster v. Illinois, 332 U.S. I34, I36-37 (1947). This provision, however, applies only to the federal courts. Betts v. Brady, $3 \times 6$ U.S. $455,46 \mathrm{I}-$ 62 (r942).

${ }^{2} 3$ I6 U.S. 455 (I942).

${ }^{3}$ See Uveges v. Pennsylvania, 335 U.S. 437, 44I (I948), where Justice Reed stated the majority opinion as being that "when a crime subject to capital punishment is not involved, each case depends on its own facts." Justice Douglas, dissenting in Bute v. Illinois, 333 U.S. 640,680 (I948), refers to the rule that counsel must be appointed in capital cases as well settled, citing Powell v. Alabama, 287 U.S. 45 (I932); Williams v. Kaiser, 323 U.S. 47 I (I945); and DeMeerleer v. Michigan, 329 U.S. 663 (I947). In Powell v. Alabama, supra, at 7r, despite the broad dictum, the holding was strictly limited to "a capital case, where the defendant is unable to employ counsel, and is incapable adequately of making his own defense because of ignorance, feeblemindedness, illiteracy, or the like..." The holding in Williams v. Kaiser, supra, at 473 , was limited to "cases of this type," and the case was of the type which was not only capital, but which involved complex distinctions between different degrees of robbery. In the DeMeerleer case the conclusion that due process had been denied was based not only on the fact that the charge was capital, but also that the defendant was very young and inexperienced, the charge complicated and the proceedings hurried. The significance of factors other than the capital or noncapital nature of the offense is discussed in note 5 infra, in connection, primarily, with noncapital cases.

In Betts v. Brady, 3I6 U.S. 455 (I942), it was pointed out that the previous statements of the Court, indicating that the right to counsel in all cases came within the safeguards of the Fourteenth Amendment, were dicta. Similarly, there have been no direct holdings that the requirement is absolute in capital cases.

4 Betts v. Brady, 3 I6 U.S. 455,473 (I942). This decision was considered by many, on as well as off the Court, to be an unjustifiable retreat from the position previously taken by the Court in Powell v. Alabama, 287 U.S. 45 (I932), and Grosjean v. American Press, 297 U.S. 233 ( 1936 ), in which cases the right to counsel was said to be fundamental. Justice Black, 